\title{
Fluorescent nucleic acid base analogues
}

\author{
L. Marcus Wilhelmsson* \\ Department of Chemical and Biological Engineering/Physical Chemistry, Chalmers University of Technology, \\ S-4I296 Gothenburg, Sweden
}

\begin{abstract}
The use of fluorescent nucleic acid base analogues is becoming increasingly important in the fields of biology, biochemistry and biophysical chemistry as well as in the field of DNA nanotechnology. The advantage of being able to incorporate a fluorescent probe molecule close to the site of examination in the nucleic acid-containing system of interest with merely a minimal perturbation to the natural structure makes fluorescent base analogues highly attractive. In recent years, there has been a growing interest in developing novel candidates in this group of fluorophores for utilization in various investigations. This review describes the different classes of fluorophores that can be used for studying nucleic acid-containing systems, with an emphasis on choosing the right kind of probe for the system under investigation. It describes the characteristics of the large group of base analogues that has an emission that is sensitive to the surrounding microenvironment and gives examples of investigations in which this group of molecules has been used so far. Furthermore, the characterization and use of fluorescent base analogues that are virtually insensitive to changes in their microenvironment are described in detail. This group of base analogues can be used in several fluorescence investigations of nucleic acids, especially in fluorescence anisotropy and fluorescence resonance energy transfer (FRET) measurements. Finally, the development and characterization of the first nucleic base analogue FRET pair, $\mathrm{tC}^{\mathrm{O}}-\mathrm{tC}_{\text {nitro, }}$, and its possible future uses are discussed.
\end{abstract}

\section{Introduction 160}

\section{Fluorescent labelling of nucleic acids $\mathbf{1 6 0}$}
2.I. External modifications 160
2.2. Internal modifications 161
2.3. Internal versus external modifications

\section{Fluorescent base analogues 162}

3.I. Environment-sensitive fluorescent base analogues
3.I.I. 2-Aminopurine (2-AP) 162
3.1.2. Pteridines 163
3.1.3. Pyrrolo-dC 164
3.1.4. Other environment-sensitive fluorescent base analogues 166

3.2. Environment-insensitive fluorescent base analogues $\quad 170$

3.2.I. Why are environment-insensitive fluorescent base analogues important? I7।

3.2.2. tC - 1,3-diaza-2-oxophenothiazine 172

3.2.3. $\mathrm{tC}^{\circ}-1,3$-diaza-2-oxophenoxazine 174

3.2.4. Development of the first base analogue FRET pair 175

* Author for correspondence: L. M. Wilhelmsson, Chalmers University of Technology, Department of Chemical Engineering/Physical Chemistry, SE-412 96 Gothenburg, Sweden.

Tel.: +46 31 7723051; Fax: + 4631 7723858; Email: marcus.wilhelmsson@chalmers.se 


\section{Conclusions 177}

\section{Acknowledgements 177}

\section{References 177}

\section{Introduction}

In the range of important techniques used for studying nucleic acid-containing systems (including e.g. nuclear magnetic resonance (NMR), X-ray crystallography, electrophoresis, footprinting, calorimetry, enzymatic methods and UV-Vis absorption), fluorescence is one of the most sensitive, versatile, easily accessible, fast and straightforward ones. For this reason, it has found use in single-molecule real-time dynamics of nucleic acids as well as proteins, cell microscopy, nucleic acid detection and nucleic acid-protein interaction measurements. Thus, fluorescence studies at both the ensemble and single-molecule level are at the fore of biochemical as well as biophysical research on nucleic acids, and will increase in importance in the expanding field of DNA nanotechnology as these constructs keep decreasing in dimensions (Aldaye \& Sleiman, 2006; Seeman, 2003; Tumpane et al. 2007). However, to investigate nucleic acids using fluorescence techniques, an emissive reporter group, a fluorophore, first has to be covalently or non-covalently introduced to the system since the nucleobases themselves are virtually nonfluorescent under normal conditions. This fluorophore labelling will be the focus of this review and most attention will be given to the covalent internal modifications and more specifically to fluorescent nucleobase analogues. Since most of the fluorescent modifications in nucleic acid research have been performed on DNA-containing systems, the review will primarily discuss these; however, for most of the modifications, one can equally well imagine using them for RNA systems.

\section{Fluorescent labelling of nucleic acids}

The lack of adequate intrinsic emission in DNA and RNA has resulted in the development of a variety of classes of molecules for fluorescent labelling of nucleic acids. One of those classes has been developed to interact non-covalently with the nucleic acid and has been used, for example, to visualize DNA in gel electrophoresis or cell microscopy. Examples of such molecules are DNA intercalators like ethidium bromide, YO (oxazole yellow) and its homodimer YOYO, as well as DNA groove binders such as 4',6-diamidino-2-phenylindole (DAPI) and Hoechst derivatives. More importantly, molecules that enable external and internal covalent modifications of nucleic acids have also been developed and will be described in more detail below.

\section{I External modifications}

Modifying nucleic acids by covalently attaching fluorophores to the backbone at the end of or within an oligonucleotide sequence, but outside the actual base stack, can be referred to as an external modification. Since there are many fluorophores commercially available for this purpose and also other ones still on the research level (Mayer et al. 2004; Varghese \& Wagenknecht, 2009), this is currently the most common way of labelling DNA. Fluorophores in the commercial class include, for example, fluorescein and rhodamine derivatives, Alexa dyes and Cy dyes. These 
<smiles>[R]c1ccc2ccc3cccc4ccc1c2c34</smiles>

(a)<smiles>[R]c1cc2ccccc2c2ccccc12</smiles>

(b)<smiles>[R]c1ccc(/C=C/c2ccccc2)cc1</smiles>

(c)

Fig. 1. Polycyclic hydrocarbons for incorporation into the nucleobase stack: (a) pyrene, $(b)$ phenanthrene and (c) stilbene. $\mathrm{R}=($ deoxy)ribose.

molecules have high to very high molar absorptivities (up to several hundred thousand) combined with a significant to very high fluorescence quantum yield depending on the nature of the system under investigation (the reader could refer to commercial sources to find details about these fluorophores). As a consequence, the fluorophores are extremely bright and, thus, especially useful as probe molecules in gel electrophoresis experiments, different fluorescence microscopy techniques, or single- or few-molecule experiments. In general, they are also more photostable than the internal fluorescent modifications that will be thoroughly discussed below.

In some cases, molecules that are primarily used for non-covalent interaction with DNA such as ethidium, YO and the other ones mentioned above have also been utilized as external modifications by means of a covalently attached linker. The increase in fluorescence upon intercalation of the covalently attached cyanine dye TO (thiazole yellow) has, for example, been used to study the duplex formation of matched and mismatched sequences aiming at specific nucleic acid detection (Svanvik et al. 2000).

\subsection{Internal modifications}

An internal modification means that the fluorophore is covalently attached aiming at replacing the nucleobase inside the base stack. In this group of molecules you find the fluorescent base analogues that are described in detail below, and also other planar aromatic compounds attached at the nucleobase position. These planar aromatics are generally different in shape and size and lack the possibility to form hydrogen bonds with the base on the opposite strand. For example, Kool et al. have replaced nucleobases with polycyclic hydrocarbons such as pyrene, phenanthrene and stilbene (Fig. 1) (Gao et al. 2002; Ren et al. 1996; Strässler et al. 1999; Wilson \& Kool, 2006). Since these modifications allow for stacking interaction inside the base stack, they can be incorporated with merely minor perturbation to the DNA structure, even though they lack the hydrogen bonding capacity. There is even an example of enzymatic incorporation of this kind of molecule by DNA polymerase (Matray \& Kool, 1999). Other interesting candidates in the group of aromatic compounds for internal modification have been developed and studied by the groups of Romesberg (Berger et al. 2000; Matsuda \& Romesberg, 2004; Ogawa et al. 2000a, b) and Benner (Piccirilli et al. 1990; Schneider \& Benner, 1990; Switzer et al. 1989, 1993). These nucleobase analogues have been shown not to destabilize the DNA and are expected not to 
distort the structure substantially. However, so far there has been no or only little effort made on examining the potential use of these analogues as fluorescent probes.

\subsection{Internal versus external modifications}

Either external or internal modification could be preferable when using fluorescence to investigate nucleic acid-containing systems. Therefore, it is impossible and incorrect to claim that a certain fluorophore or even group of fluorophores is, overall, best suited for fluorescently modifying DNA. Instead one needs to carefully consider each system under examination and try to optimize the choice of fluorescent probe molecule thereafter.

Generally, as mentioned above, the external commercially available fluorophores are very bright and photostable. Sometimes it is also preferable to have the probe molecule covalently attached via a long flexible linker and, thus, far from the site of interest. However, for investigations where the level of detail needs to be high, a modification in which a fluorescent base analogue is incorporated is generally preferable, since this enables the probe to be very close to the site of examination. Also, the bulkiness of the external fluorophores could give rise to problems concerning the binding of other molecules to the nucleic acid. Moreover, a modification in which a fluorescent base analogue is used normally minimizes perturbations to the native structure and behaviour of the nucleic acid. Consequently, measuring properties of the nucleic acid systems using internal modifications, especially fluorescent base analogues, normally results in an answer that is closer to the native behaviour than when using external modifications.

\section{Fluorescent base analogues}

It could be discussed how fluorescent 'base analogues' should be defined. Occasionally even molecules that (1) lack the ability to form hydrogen bonds to any of the natural bases and are considerably larger than a normal nucleobase as well as (2) natural nucleobases with externally covalently attached fluorophores are referred to as fluorescent base analogues. In this review, however, the term fluorescent base analogue will be used merely for significantly fluorescent molecules that resemble the shape of the natural nucleobases and also have some ability to form hydrogen bonds to a base in the complementary strand, i.e., they should not seriously perturb the overall structure of the nucleic acid.

\section{I Environment-sensitive fluorescent base analogues}

With the exception of the family of tricyclic cytosines presented later in this review in section 3.2, all fluorescent base analogues have a quantum yield that is somewhat to highly sensitive to their immediate surroundings. Factors such as hydrogen bonding (Wilhelmsson et al. 2003), single- or double-stranded environment, and neighbouring base are important factors governing the fluorescence quantum yield of a base analogue inside the base stack. Generally, fluorescent base analogues are highly quenched inside DNA, and normally the effect is most significant if surrounded by neighbouring purines (see e.g. Hawkins, 2001; Rachofsky et al. 2001; Ward et al. 1969).

\subsection{2-Aminopurine (2-AP)}

In 1969 Ward et al. discovered that 2-AP (Fig. 2) (Ward et al. 1969), currently the most used fluorescent base analogue, is highly fluorescent. 2-AP, which is one of the few commercially 
<smiles></smiles>

(a)<smiles></smiles>

(b)

Fig. 2. Fluorescent base analogue 2 -AP base paired with thymine $(a)$ and cytosine $(b) . \mathrm{R}=($ deoxy)ribose.

available fluorescent base analogues, is an adenine (6-AP) analogue forming stable base pairs with thymine (Fig. $2 a$ ) and uracil but also moderately stable base pairs with cytosine (Fig. 2b) (Freese, 1959; Sowers et al. 1986, 2000). The lowest energy absorption band of 2-AP is centred at $305 \mathrm{~nm}$ and has a molar absorptivity $(\varepsilon)$ of $6000 \mathrm{M}^{-1} \mathrm{~cm}^{-1}$ (Albert \& Taguchi, 1973; Holmén et al. 1997). The position of the band is outside the absorption of the nucleic acid and, thus, 2-AP can be selectively excited in the presence of the natural nucleobases.

The high fluorescence quantum yield of 2-AP free in solution $(0 \cdot 68)$ is considerably reduced ( $\sim 100$ times but highly dependent on base sequence) when incorporated into nucleic acids (Ward et al. 1969). This sensitivity to the microenvironment has been utilized in a range of investigations, including nucleic acid structure and dynamics (Guest et al. 1991; Rachofsky et al. 2001; Stivers, 1998). This property of 2-AP has also been utilized to study DNA-protein interactions such as the interaction with the EcoRI DNA methyltransferase (Allan \& Reich, 1996), the Klenow fragment of DNA polymerase (Bloom et al. 1993; Hochstrasser et al. 1994; Joyce et al. 2008), the EcoRI endonuclease (Lycksell et al. 1987; Nordlund et al. 1989) and the uracil DNA glycosylate (Stivers et al. 1999). More recently, 2-AP has been used as a probe in the rapidly expanding field of small RNAs and RNA elements that control gene expression at a number of levels. For example, the groups of Lilley and Batey have investigated riboswitch folding properties and thermodynamics as well as kinetics of ligand binding to the purine riboswitch aptamer domain (Gilbert et al. 2006; Lemay et al. 2006). On a rather different subject, 2-AP has also found use in studies of photo-induced electron transfer through the DNA stack (Kelley \& Barton, 1999).

As illustrated above, the sensitivity of the emission of 2-AP to the microenvironment is very useful. However, the less efficient and less specific base-pairing relative to adenine introduces a perturbation to the native structure of DNA and also gives 2-AP increased dynamics within the DNA helix. This, in combination with the sensitivity of the fluorescence quantum yield to the environment, makes 2-AP less suited as a probe for studies of molecular dynamics and DNA-protein interaction using techniques such as fluorescence anisotropy and fluorescence resonance energy transfer (FRET).

\subsubsection{Pteridines}

An interesting and frequently utilized family of fluorescent base analogues are the pteridines mainly developed by Hawkins and Pfleiderer (Hawkins, 2001). The most promising analogues 
<smiles>[R]c1nc2c(=O)n([R])c(N)nc2n([R])c1=O</smiles>

3-MI: $\mathrm{R}_{1}=\mathrm{CH}_{3} ; \mathrm{R}_{2}=\mathrm{H}$

6-MI: $\mathrm{R}_{1}=\mathrm{H} ; \mathrm{R}_{2}=\mathrm{CH}_{3}$

(a)<smiles>[R]c1nc(N)c2nc(C)c(=O)n([R])c2n1</smiles>

DMAP: $\mathrm{R}_{1}=\mathrm{CH}_{3}$

6-MAP: $\mathrm{R}_{1}=\mathrm{H}$

(b)

Fig. 3. Fluorescent guanine analogues 3-MI and 6-MI (a) and fluorescent adenine analogues DMAP and 6-MAP (b). $\mathrm{R}=($ deoxy)ribose.

within this family are the guanine analogues 3-MI and 6-MI (Fig. $3 a$ ) and the adenine analogues 6-MAP and DMAP (Fig. 3b). Like 2-AP, these probes are very sensitive to the microenvironment and are highly quenched, with fluorescence quantum yields ranging from $<0.01$ to 0.3 depending on the nature of the surrounding base pairs, when incorporated into DNA (Hawkins, 2001; Hawkins et al. 1995, 1997, 2001). The lowest energy excitation maxima for both the adenine and guanine analogues are located between 310 and $350 \mathrm{~nm}$, and are thus well resolved from the absorption of the natural nucleobases and easy to selectively excite. The molar absorptivities of the low-energy transition of the pteridine base analogues are not extensively examined; however, values between 5000 and $15000 \mathrm{M}^{-1} \mathrm{~cm}^{-1}$ have been reported, e.g. 6-MAP in methanol $\varepsilon_{329}=8500 \mathrm{M}^{-1} \mathrm{~cm}^{-1}$ (Stanley et al. 2005) and 3-MI in water $\varepsilon_{351}=13000 \mathrm{M}^{-1} \mathrm{~cm}^{-1}$ (Sanabia et al. 2004). A slight drawback with this group of fluorescent base analogues is that duplex melting temperature studies have shown that, with the exception of 6-MI, they reduce the thermal stability of oligonucleotides (Hawkins et al. 1997, 2001). For example, as an effect of the methyl group in the 3-position of 3-MI, the hydrogen bonding to cytosine is hindered, resulting in a reduced stability approximately equivalent to a single base-pair mismatch.

The fluorescent pteridines have already been successfully utilized in a range of investigations. 3-MI has among other things, been utilized in a real-time assay for $O^{6}$-alkylguanine-DNA alkyltransferase (Moser et al. 2000), DNA binding of the non-specific histone-like protein HU (Wojtuszewski et al. 2001), and as a probe of hybridization specificity (Hawkins \& Balis, 2004). Furthermore, 3-MI has been evaluated for single-molecule detection purposes (Sanabia et al. 2004). The other guanine analogue, 6-MI, has been used in recombination to study the mechanism of the RecA-mediated DNA strand exchange (Roca \& Singleton, 2003; Xiao et al. 2006) as well as in structural studies of the RecA-DNA filament (Singleton et al. 2007). The adenine analogue 6-MAP, on the other hand, has been used in premelting transition studies of DNA A-tracts (Augustyn et al. 2006) and as a probe for base flipping by DNA photolyase (Yang et al. 2007).

\subsubsection{Pyrrolo-dC}

In the late 1980s, Inoue and co-workers reported on the fluorescence properties of the pyrrolo$\mathrm{dC}$ derivative $\mathrm{dF}^{*}$ (Fig. 4a) inside an oligonucleotide (Inoue et al. 1987), which was a follow-up on their studies on dF (Fig. 4b) some years earlier (Bergstrom et al. 1982). In those studies, it was also found that an $F^{*} \cdot G$ base pair had a stability similar to that of a $C \cdot G$ base pair. Later a 
<smiles>[R]n1cc2cc[nH]c2nc1=O</smiles>

(a)<smiles>[R]n1cc2ccc(=O)[nH]c2nc1=O</smiles>

(b)<smiles>[R]n1cc2cc(C)oc2nc1=O</smiles>

(c)<smiles>[R]n1cc2cc(C)[nH]c2nc1=O</smiles>

(d)

Fig. 4. Fluorescent base analogues in the pyrrolo-dC-'family': (a) dF*, (b) dF, (c) furano-dT and (d) pyrrolodC. $\mathrm{R}=($ deoxy) ribose.

fluorescent nucleobase named furano-dT (Fig. 4c) was introduced (Woo et al. 1996). However, after incorporation of this non-specific nucleobase into an oligonucleotide and the subsequent ammonia treatment at the final stage of the DNA solid-phase synthesis, it was found that the nucleobase had reacted to form the C-analogue pyrrolocytosine (pyrrolo-dC; Fig. 4d) (Berry et al. 2004). This fluorescent base analogue is a 6-methyl derivative of the previously mentioned $\mathrm{dF}^{*}$ (Fig. 4a). It has been shown in several studies that pyrrolo-dC hybridizes selectively with $G$ $(\mathrm{dG}>>\mathrm{dT}>\mathrm{dA}>\mathrm{dC})$ and that duplexes containing pyrrolo-dC in place of $\mathrm{dC}$ are virtually as stable as the corresponding unmodified ones (Berry et al. 2004). As for the pteridines mentioned above, this commercially available fluorescent base analogue can be selectively excited since the low-energy absorption band at $350 \mathrm{~nm}\left(\varepsilon_{350}=5900 \mathrm{M}^{-1} \mathrm{~cm}^{-1}\right)$ is well separated from both nucleic acid and protein absorption (Liu \& Martin, 2001). The emission maxima for the pyrrolo$\mathrm{dC}$ monomer before and after incorporation into duplex contexts are 460 and $473 \mathrm{~nm}$, respectively. The fluorescence quantum yield of the monomer has been reported to be $0 \cdot 20$ (Liu \& Martin, 2001). However, after incorporation into a single strand the quantum yield drops significantly and subsequent hybridization with a complementary strand to form a duplex reduces the quantum yield even more (Berry et al. 2004; Dash et al. 2004; Hardman \& Thompson, 2006; Liu \& Martin, 2001). Very little has been reported on the influence of neighbouring bases on the quantum yield of pyrrolo-dC; however, quantum yields of 0.03 in dsDNA (TT neighbours) and approximately 0.05 in dsRNA (CA neighbours) have been reported.

Since pyrrolo-dC is commercially available, it has already been used in several biochemical applications. In the study by Liu and Martin, at the time when it was found that furano-dT modified strands actually were transformed to pyrrolo-dC during the DNA solid-phase synthesis, they used the fluorescence of the C-analogue to characterize the transcription bubble in the elongation complexes of the T7 RNA polymerase (Liu \& Martin, 2001). Later, in 2005 Zang et al. utilized pyrrolo-dC to examine the kinetics of parts of the repair of damaged DNA by a human alkyltransferase (Zang et al. 2005). Furthermore, pyrrolo-dC has been incorporated into DNA strands that subsequently have been annealed with an RNA strand to form a DNA/RNA hybrid and used to investigate the HIV-1 polypurine tract (PPT) in which abnormal base pairing 


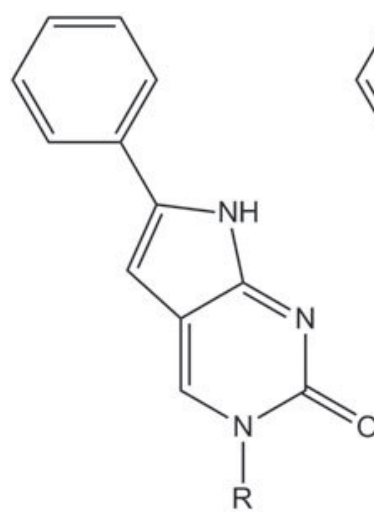

(a)

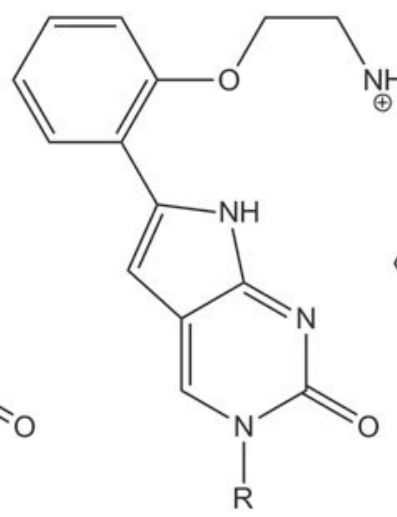

(b)

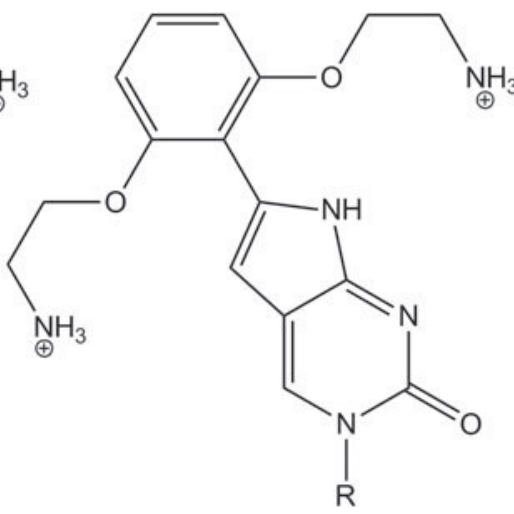

(c)

Fig. 5. Phenyl derivatives of pyrrolo-dC: (a) PhpC, (b) moPhpC and (c) boPhpC. R=(deoxy)ribose.

has been reported (Dash et al. 2004). In the search for high-affinity and highly selective triplexforming oligonucleotides (TFOs), the groups of Brown and Fox have developed methylated pyrrolo-dC derivatives for use in the duplex recognition strand (Ranasinghe et al. 2005). These derivatives might be interesting as fluorescent probes for DNA triplexes, but this has so far not been investigated. In a different approach optimizing the wavelength of excitation and emission as well as the position of the involved probes, Turro and co-workers have shown that pyrrolo-dC can be utilized in pair with 2-AP in a molecular beacon-like fashion (Marti et al. 2006). Recently pyrrolo-dC has also been used for investigating the structure and thermodynamics of single strands that are able to form DNA hairpins (Zhang \& Wadkins, 2009), the secondary structure of RNA (Tinsley \& Walter, 2006) as well as the propagation of base-pair flipping in a DNA photolyase complex (Yang \& Stanley, 2008).

\subsubsection{Other environment-sensitive fluorescent base analogues}

With the aim of improving both the hybridization and fluorescence properties of the abovementioned pyrrolo-dC, the group of Hudson started to substitute the 6-methyl group with various molecular entities with a focus on phenyl derivatives ( $\mathrm{PhpC}$, moPhpC and boPhpC; Fig. 5) (Hudson et al. 2003; Wojciechowski \& Hudson, 2008). These phenyl derivatives show increased duplex (peptide nucleic acid (PNA)/DNA hybrid) stability compared to the unmodified case, good base-pairing selectivity and a promisingly high fluorescence quantum yield. The reported quantum yield for boPhcP monomer in aqueous solution is 0.32 (approx. $50 \%$ higher than pyrrolo-dC), whereas it was found to be approximately 50 and $25 \%$ in the two investigated single and double strands, respectively (Wojciechowski \& Hudson, 2008). The high quantum yield in the single-stranded PNAs and in the PNA/DNA hybrids in combination with the molar absorptivity of $6650 \mathrm{M}^{-1} \mathrm{~cm}^{-1}$ at $365 \mathrm{~nm}$ makes this base analogue an interesting fluorescent probe. However, the dependence of the quantum yield on surrounding bases still remains to be studied. Recently, boPhpC was incorporated into antisense PNA, and it was demonstrated that the stability of boPhcP-PNA/RNA duplexes was increased ( $\mathrm{Hu}$ et al. 2009). In another effort to increase the stability of (hybrid) duplexes, the group of Hudson 
<smiles>[R]n1cc2c(nc1=O)NC(=O)NC2</smiles>

(a)<smiles>[R]n1cc2c(nc(=O)n3cccc23)[nH]c1=O</smiles>

(b)

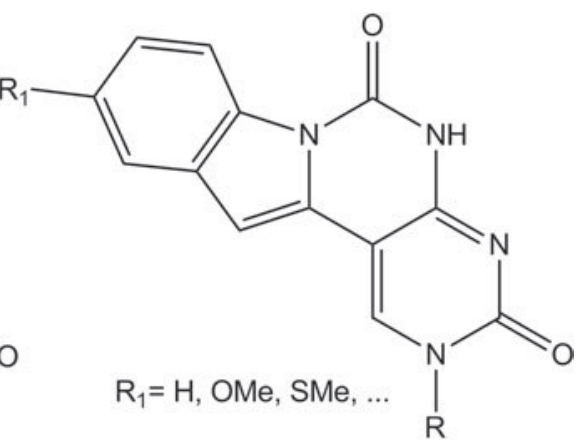

(c)

Fig. 6. Fluorescent cytosine analogues developed by Sekine et al: : (a) $\mathrm{dC}^{\text {hPp }},(b) \mathrm{dC}^{\mathrm{PPP}}$ and $(c) \mathrm{dC}^{\mathrm{PPI}}$. $\mathrm{R}=($ deoxy) ribose.

developed additional modifications of $\mathrm{PhpC}$ that also show fluorescence properties (Wojciechowski \& Hudson, 2009). Other derivatives of pyrrolocytosine have also been developed and incorporated into nucleic acid, and their quantum yields have been determined to be relatively low $\left(\varphi_{f} \approx 0.06\right)$ (Seela \& Sirivolu, 2008).

Sekine et al. have focused on another group of fluorescent cytosine analogues, where they have expanded the cytosine one-ring system to different two-, three- and four-ring systems while maintaining the hydrogen bonding possibilities with guanine (Fig. 6). The two-ring cytosine analogue, $\mathrm{dC}^{\text {hpp }}$ (Fig. 6a), has been investigated for its fluorescence in DNA single and double strands (Miyata et al. 2006). The emission in the single-stranded case has a peak at approximately $370 \mathrm{~nm}$ that is considerably quenched upon hybridization with a complementary strand ( $G$ opposite). However, having a mismatch A opposite the $\mathrm{dC}^{\text {hpp }}$ keeps the emission virtually unchanged relative to the single-stranded case. Furthermore, it has been shown that $\mathrm{dC}^{\text {hpp }}$ forms not only stable base pairs with $G$ but also fairly stable ones with $A$, where the melting temperature is increased by $10{ }^{\circ} \mathrm{C}$ compared to the corresponding $\mathrm{C}-\mathrm{A}$ mismatch. The quantum yield of $\mathrm{d} \mathrm{C}^{\text {hpp }}$ inside DNA has not been reported but has been measured for the monomeric form $\left(\varphi_{f}=0 \cdot 12\right)$ (Miyata et al. 2006). To improve the fluorescence properties and also red-shift the wavelength of excitation compared to $\mathrm{d}^{\mathrm{hpp}}\left(\lambda_{\max }=300 \mathrm{~nm}\right)$, a third ring was attached to the system to form the cytosine analogue $\mathrm{dC}^{\mathrm{pPp}}$ (Fig. 6 b) (Miyata et al. 2007). This analogue has an excitation maximum in the low-energy band at $360 \mathrm{~nm}$ and an emission maximum at $490 \mathrm{~nm}$ with a quantum yield of approximately $0 \cdot 11$, but has not yet been investigated inside nucleic acid sequences. In yet another study concerning cytosine analogues, Sekine et al. attached an additional ring to $\mathrm{dC}^{\mathrm{PPP}}$ forming various derivatives of $\mathrm{dC}^{\mathrm{PPI}}$ (Fig. 6c) (Mizuta et al. 2007). The unsubstituted $\mathrm{dC}^{\mathrm{PPI}}$ was shown to have a quantum yield that was reduced almost 20 times compared to the parent compound $\mathrm{dC}^{\mathrm{PPP}}$. For some of the other derivatives of $\mathrm{dC}^{\mathrm{PPI}}$, a quantum yield comparable to $\mathrm{dC}^{\mathrm{PPP}}$ as well as both excitation and emission maxima that were slightly red-shifted were found (Mizuta et al. 2007). As for the bicyclic $\mathrm{dC}^{\text {hpp }}$, the $\mathrm{dC}^{\text {PPI }}$ derivatives form stable base pairs with $G$ and fairly stable ones with A (Mizuta et al. 2009). Moreover, the quantum yields on average decrease in going from single strands $\left(\varphi_{f} \approx 0 \cdot 06\right)$ to fully complementary duplexes $\left(\varphi_{f} \approx 0 \cdot 015\right)$. However, for one of the derivatives where $\mathrm{dC}^{\mathrm{PPI}}$ mismatches with a $\mathrm{C}$, the quantum yield has been shown to be as high as 0.27 (Mizuta et al. 2009). It should be noted 
<smiles>[R]n1cc2c(nc1=O)[nH]c(=O)c1ccccc12</smiles>

(a)<smiles>[R]n1cc2c(nc1=O)[nH]c(=O)c1c3ccccc3ccc21</smiles>

(b)<smiles>[R]n1c2ccc(OC)cc2c2c(N)ncnc21</smiles>

(c)<smiles>[R]n1c2ccc(OC)cc2c2c(=O)[nH]cnc21</smiles>

(d)

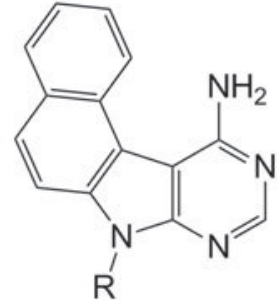

(e)

Fig. 7. BDF nucleoside analogues by Saito et al.: (a) BPP, (b) NPP, (c) ${ }^{\mathrm{MD}} \mathrm{A},(d){ }^{\mathrm{MD}} \mathrm{I}$ and $(e){ }^{\mathrm{ND}} \mathrm{A}$. $\mathrm{R}=$ (deoxy)ribose.

that the influence of different surrounding bases on quantum yield has not been investigated in detail. The three- and four-ring systems have also been investigated in a recent study, where they were utilized as base analogues that could increase the stability of DNA triplexes (Mizuta et al. 2008).

The group of Saito has developed a range of base-discriminating fluorescent (BDF) nucleoside analogues (Okamoto et al. 2005). Many of these have common fluorophores covalently attached to a normal nucleobase and show promising properties (Bag et al. 2006; Saito et al. 2005, 2006, 2007, 2008; Tainaka et al. 2007); however, as mentioned above, here the focus will be on internal fluorescent base analogues. The fluorescent base analogue BPP (Fig. 7 a) has an absorption maximum around $350 \mathrm{~nm}$, well separated from the nucleobases, and an emission centred at approximately $390 \mathrm{~nm}$ (Okamoto et al. 2003a). It has a considerable similarity with the base analogues by Sekine et al., can form stable base pairs with both A and G, and can be utilized to discriminate between the two purines using the change in quantum yield when base paired with a $G\left(\varphi_{f} \approx 0.0018\right)$ or an A $\left(\varphi_{f} \approx 0.035\right)$ (Okamoto et al. 2003a). The structurally related NPP (Fig. $7 b$ ), having an additional benzene ring compared to BPP, has also been shown to have base-discriminating properties (Okamoto et al. 2003b). The peak of emission is found around $420 \mathrm{~nm}$ and the quantum yield again depends on base pairing with $G\left(\varphi_{f} \approx 0 \cdot 007\right)$ or $\mathrm{A}\left(\varphi_{f} \approx 0.096\right)$. Using a combination of the two fluorescent base analogues ${ }^{\mathrm{MD}} \mathrm{A}$ and ${ }^{\mathrm{MD}} \mathrm{I}(\mathrm{Fig} .7 \mathrm{c}$ and $d$ ) has been suggested to be a powerful tool for T/C single nucleotide polymorphism (SNP) typing (Okamoto et al. 2003c). In combination with $C$ in the complementary strand, a quantum yield of 0.081 and a peak at $424 \mathrm{~nm}$ have been observed for ${ }^{\mathrm{MD}} \mathrm{A}$. For all other base-pair combinations, the quantum yield was found to be lower. The corresponding values for ${ }^{\mathrm{MD}} \mathrm{I}$ $\left(\varphi_{f} \approx 0.011 ; \mathrm{Em}_{\max }=424 \mathrm{~nm}\right)$ are found in combination with $\mathrm{T}$ in the complementary strand. 


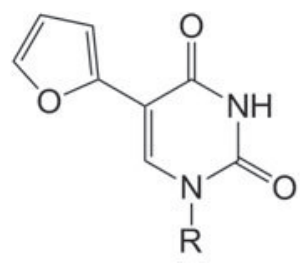

(a)<smiles>[R]n1cc(-c2ccco2)c(N)nc1=O</smiles>

(b)

Fig. 8. Fluorescent furan-modified pyrimidines: (a) thymine analogue and (b) cytosine analogue. $\mathrm{R}=$ (deoxy)ribose.

Finally, Saito and co-workers have used another BDF nucleoside, ${ }^{\mathrm{ND}} \mathrm{A}$ (Fig. 7 e), in FRET in combination with fluorescein to distinguish $C$ from all other bases (Okamoto et al. 2004).

Important contributions to the field of fluorescent nucleobase analogues have also been made by the group of Tor. In an attempt to develop emissive nucleosides that have a high sensitivity to the microenvironment, they attached different five-membered heterocycles to both pyrimidines and purines (Fig. 8). Although the eight-modified purines show favourably high quantum yields in water $(0.69$ and 0.57 for the adenine and guanine analogue, respectively) (Greco \& Tor, 2007), the research has focused on the 5-position furan-modified T/U (Fig. 8 a) due to its high responsiveness to the surrounding microenvironment (Greco \& Tor, 2005, 2007). The fluorescence quantum yield of this thymine (or uridine) analogue in water has been determined to be 0.03 and the corresponding maxima in the lowest energy absorption band and the fluorescence have been shown to be at 316 and $431 \mathrm{~nm}$, respectively. It has been successfully incorporated into DNA sequences, where it is still emissive in both single- and double-stranded systems (Greco \& Tor, 2007). Moreover, the stability of a furan-dT-modified oligonucleotide has been shown to be exactly the same as that of the corresponding unmodified sequence. It has been shown to be useful for abasic site detection (Greco \& Tor, 2005) as well as major groove polarity measurements in DNA (Sinkeldam et al. 2008). Furthermore, the related uridine analogue has been synthesized in its triphosphate form for subsequent successful exploitation as in RNA HIV-1 TAR recognition studies (Srivatsan \& Tor, 2007b) and as a substrate in in vitro transcription reactions using the T7 RNA polymerase (Srivatsan \& Tor, 2007a). Additionally, the furan derivative of cytosine (Fig. 8b) shows similar photophysical properties as its thymine counterpart, works very well as a C-analogue, and has been shown to efficiently distinguish between $\mathrm{G}, 8$-oxoG and $\mathrm{T}$ in a non-destructive method for in vitro detection of a DNA oxidative damage pathway (Greco et al. 2009).

Tor et al. have also designed and developed new isomorphic fluorescent nucleobase analogues using the thieno[3,2-d]- or thieno[3,4-d]-pyrimidine core (Srivatsan et al. 2008b; Tor et al. 2007). The thieno[3,2-d]pyrimidine T-analogue (Fig. 9 a) has been shown to have a quantum yield in water of approximately 0.06 and the corresponding maxima in the lowest energy absorption band and the fluorescence have been shown to be situated at 292 and $351 \mathrm{~nm}$, respectively. Corresponding values for the thieno[3,4-d]pyrimidine T-analogue (Fig. 9b) are $\varphi_{f} \approx 0.50,304 \mathrm{~nm}$ and $412 \mathrm{~nm}$ (Srivatsan et al. 2008b). Thus, this T-analogue has a more promising quantum yield as well as a low-energy absorption band that is more well separated from the intrinsic nucleic acid absorption. It has been synthesized in its triphosphate form, and enzymatically incorporated into RNA oligonucleotides (Srivatsan \& Tor, 2009) and has also 
<smiles>[R]n1c(=O)[nH]c(=O)c2sccc21</smiles>

(a)<smiles>[R]n1c(=O)[nH]c(=O)c2cscc21</smiles>

(b)

Fig. 9. Fluorescent thymine analogues developed by Tor et al:: (a) thieno[3,2-d]pyrimidine and (b) thieno[3,4-d]pyrimidine. $\mathrm{R}=$ (deoxy)ribose.

been used for sensing mismatch pairing and signalling the activity of toxic ribosome-inactivating proteins (Srivatsan et al. 2008a).

Recently, the group of Tor designed and synthesized the uracil base analogue, 5-methoxyquinazoline-2,4-(1H,3H)-dione, and incorporated it into RNA (Xie et al. 2009). This base analogue has an emission maximum at $395 \mathrm{~nm}$ with a quantum yield of 0.16 in its monomeric form that drops to 0.03 inside the RNA construct. With an absorption maximum at $320 \mathrm{~nm}$, this $\mathrm{U}$-analogue is easily selectively excited and for the sequence used in the investigation it has minimal influence on the stability of the folded RNA. In the investigation, the authors use the U-analogue as a FRET donor in pair with coumarin-labelled aminoglycosides and demonstrate the use of this pair as an analysis and discovery platform for antibiotics targeting the bacterial rRNA A-site.

5-Methylpyrimidin-2-one (Fig. 10a) is referred to as a fluorescent T-analogue (Laland \& Serckhanssen, 1964). It has been shown to be predominantly stacked in oligonucleotide context; however, it does not base-pair well with A. It has its excitation and emission maxima at 310 and $380 \mathrm{~nm}$, respectively, and the emission is efficiently quenched when the base analogue is inside the base stack. Apart from base (un)stacking determinations (Wu et al. 1990), it has been used for probing the RecA nucleoprotein filament (Singleton et al. 2001). Other fluorescent base analogues worth mentioning are the 7-deazapurines (Fig. 10b) studied by Seela et al. (Seela \& Zulauf, 1998; Seela et al. 2000), the 5-alkynyluridines (Fig. 10c) of Hudson \& GhorbaniChoghamarani (2007), the benzoquinazolines (Fig. 10d) of Godde, Toulmé and Moreau that have been utilized in triplexes (Godde et al. 1998, 2000), the triazoleadenosines (Fig. 10e) of Wilhelmsson and Grøtli (Dyrager et al. 2009) and last but definitely not the least the 1, $N^{6}$-ethenoadenosine (Fig. 10f) that was developed, investigated and utilized by Secrist et al. already in the early 1970s (Secrist et al. 1972).

\subsection{Environment-insensitive fluorescent base analogues}

The base analogues described in previous sections all have an emission that is highly sensitive to their immediate surroundings. 2-AP, for example, has a quantum yield of 0.68 as a monomer, but is quenched approximately 100 times upon incorporation into a DNA duplex (Ward et al. 1969). Another example of how sensitive these base analogues are to the microenvironment are the pteridines that can have quantum yields that change up to 30 times depending on the nature of the surrounding bases (Hawkins, 2001; Hawkins et al. 1997, 2001). In this section, fluorescent base analogues that have quantum yields that are essentially or fairly insensitive to the immediate surroundings of the analogue and their use will be discussed. 
<smiles>[R]n1cc(C)cnc1=O</smiles>

(a)<smiles>[R]c1c([R])n([R])c2ncnc(N)c12</smiles>

(b)<smiles>[R]C#Cc1cn([R])c(=O)[nH]c1=O</smiles>

(c)<smiles>[R]n1c(=O)nc(N)c2cc3ccccc3cc21</smiles><smiles>[R]n1c(=O)[nH]c(=O)c2cc3ccccc3cc21</smiles>

(d)<smiles>[R]n1cc(-c2nc3c(N)ncnc3n2[R])nn1</smiles>

(e)<smiles>[R]n1cnc2c1ncn1ccnc21</smiles>

(f)

Fig. 10. Fluorescent base analogues (a) 5-methylpyrimidin-2-one, (b) 7-deazapurines, (c) 5-alkynyluridines, $(d)$ benzoquinazolines, $(e)$ triazoleadenosines and $(f) 1, N^{6}$-ethenoadenosine. $\mathrm{R}=($ deoxy $)$ ribose.

\subsection{Why are environment-insensitive fluorescent base analogues important?}

At first consideration, it may be easy to think that an environment-sensitive fluorescent probe is always more useful than an insensitive one. However, in experiments where the emission is used merely for detection, a high and stable quantum yield in combination with a high molar absorptivity (brightness $\propto \varphi_{f} \varepsilon$ ) is more important. Moreover and more importantly for the fluorescent base analogues that are environment insensitive is their use in FRET and anisotropy measurements. For these kinds of experiments, the high and virtually unaffected quantum yield and the single fluorescence lifetime in combination with the high control of orientation and position within the nucleic acid are essential properties that are unique for the base analogues of the $\mathrm{tC}$ family discussed below. As will be described in detail later in the text, a stable quantum yield $\left(\varphi_{f}\right)$ and high control of position and orientation $\left(\kappa^{2}\right)$ are crucial in accurately determining the Förster distance $\left(R_{0}\right)$ and, thus, also for the precision of distances $\left(R_{\mathrm{DA}}\right)$ estimated using FRET. Furthermore, a single lifetime and strong emission in combination with a firm stacking within the base stack is essential for accurately determining the mobility of nucleic acids using fluorescence anisotropy. 


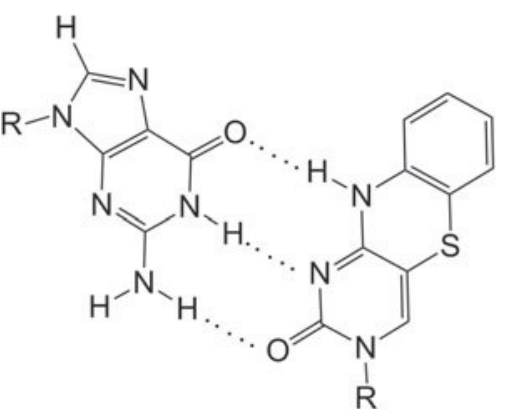

(a)<smiles>[R]n1cc2c(nc1=O)Nc1ccccc1O2</smiles>

(b)<smiles>[R]n1cc2c(nc1=O)Nc1ccc([N+](=O)[O-])cc1S2</smiles>

(c)

Fig. 11. Tricyclic cytosine analogues: (a) guanine base paired with $\mathrm{tC}$, which displays a virtually environment-insensitive emission quantum yield, (b) highly emissive $\mathrm{tC}^{\mathrm{O}}$ and $(c)$ base analogue FRET acceptor $\mathrm{tC}_{\text {nitro }} \mathrm{R}=($ deoxy $)$ ribose.

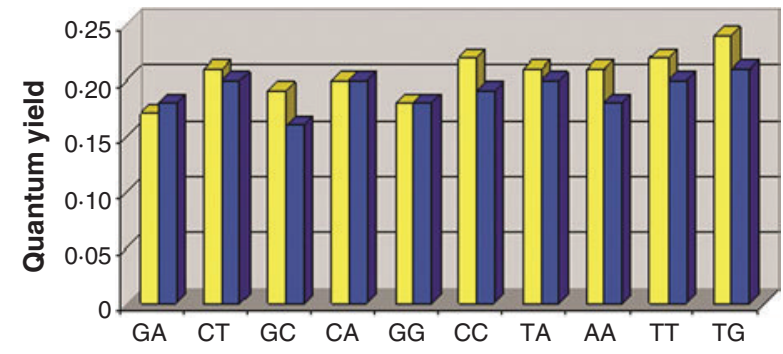

Fig. 12. Fluorescence quantum yield of tC in DNA single- (yellow) and double-stranded (blue) systems. Letters denote bases surrounding $\mathrm{tC}\left(5^{\prime}-\ldots \mathbf{X}(\mathrm{tC}) \mathbf{Y} \ldots-3\right)$.

\subsection{2 tC - 1,3-diaza-2-oxophenothiazine}

The tricyclic cytosine analogue tC (Fig. 11a), 1,3-diaza-2-oxophenothiazine, was originally developed by Matteucci and co-workers for antisense purposes (Lin et al. 1995). Several years later we found that $\mathrm{tC}$ is highly fluorescent with an emission maximum at $505 \mathrm{~nm}$ and has a quantum yield that is roughly the same in the monomeric form, in a PNA single strand and in a PNA-DNA hybrid duplex (Wilhelmsson et al. 2001). Later, using a set of ten different base-pair surroundings, we could conclude that $\mathrm{tC}$ in fact has a fluorescence quantum yield that is virtually unaffected by its immediate surroundings (Fig. 12) (Sandin et al. 2005, 2007). The quantum yields in single- and double-stranded systems are found to be $0 \cdot 17-0 \cdot 24$ and $0 \cdot 16-0 \cdot 21$, respectively. Furthermore, we found that $\mathrm{tC}$ displays single fluorescence lifetimes in both single and double strands $\left(\tau_{f}(\mathrm{ss})=5.7 \mathrm{~ns}\right.$ and $\tau_{f}(\mathrm{ds})=6.3 \mathrm{~ns}$ averaged over the ten sequences). The lowest energy absorption band centred around $395 \mathrm{~nm}$ in duplex DNA is very well separated from the absorption of the natural nucleobases and tC can hence be selectively excited (Wilhelmsson et al. 2003). This band consists of a single electronic transition polarized $35^{\circ}$ counterclockwise from the long axis of $\mathrm{tC}$ (Wilhelmsson et al. 2003): parameters that are essential for further use in FRET experiments (vide infra). 
Earlier it was found that $\mathrm{tC}$ is a good cytosine analogue (Eldrup et al. 2001; Lin et al. 1995). It base-pairs with guanine and discriminates well between guanine and adenine (Lin et al. 1995). Using NMR, we have discovered that DNA adopts a normal B-form after incorporation of $\mathrm{tC}$ in place of cytosine and that only minor local distortions are present in the vicinity of $\mathrm{tC}$ (Engman et al. 2004). The overall bent tC-DNA NMR-structure conformation suggested in that NMR article is most likely an effect of the difficulties to draw conclusions regarding long-range features based on the short-range information provided by nuclear overhauser effect (NOEs) and torsion angle constraints. NMR data further confirm correct base pairing and a baseflipping rate of $\mathrm{tC}$ that is equal to the natural bases. Moreover, we found that the circular dichroism (CD) of the ten investigated $\mathrm{tC}$ duplexes showed features consistent with $\mathrm{B}$-form DNA. We also discovered that one $\mathrm{tC}$ on average increases the stability of a 10 -mer duplex by approximately $3{ }^{\circ} \mathrm{C}$ (Engman et al. 2004). These findings all suggest that tC does not perturb the DNA structure significantly and that it is firmly stacked with a well-defined geometry (orientation) inside the DNA helix.

The firm stacking, low base-flipping rate, and single and comparably long fluorescence lifetime of $\mathrm{tC}$ in duplex is a set of truly unique properties for a fluorescent base analogue. These properties are central in studying the overall motion of nucleic acid structures without interference from any motions of the fluorescent probe itself. In a recent study, we show strong evidence that $\mathrm{tC}$ works excellently as a probe for monitoring motions of the overall nucleic acid structure rather than a combination of motion of the overall structure and the probe itself (Sandin et al. 2008), as is the case for fluorescent base analogues that are not firmly stacked, or has increased base-flipping rates. Furthermore, we have utilized tC as a FRET donor in pair with rhodamine in a PNA-DNA hybrid (Wilhelmsson et al. 2001), and in pair with Alexa-555 in a study of conformational dynamics of DNA polymerase (Stengel et al. 2007). In the latter study, tC was present adjacent to the primer $3^{\prime}$ terminus of the DNA primer/template that was bound in the active site of the polymerase. In another polymerase study, we show that the $5^{\prime}$-triphosphate of $\mathrm{tC}$ (and $\mathrm{tC}^{\mathrm{O}}$, vide infra), which was synthesized for the first time, is efficiently incorporated into DNA by the Klenow fragment (Sandin et al. 2009a). This shows that the active site of the Klenow fragment is flexible enough to tolerate these size-expanded bases and constitutes the first report where the insertion of a sizeexpanded base is demonstrated to be more efficient than the corresponding natural base. However, we also find that $\mathrm{tC}^{(\mathrm{O})}$ can be misincorporated opposite adenine, which suggests that there is a loss of selectivity (Sandin et al. 2009a). In a later comprehensive study by Stengel $e t$ al. using also the human DNA polymerase $\alpha$, a similar conclusion could be drawn about the efficiency and loss of selectivity (Stengel et al. 2009a). Furthermore, they show that $\mathrm{tC}^{(\mathrm{O})}$ works well as templating bases and suggest that different tautomeric forms of $\mathrm{tC}^{(\mathrm{O})}$ might explain the loss of selectivity since the imino-form could base-pair with adenine. In a related study by the same group, it was shown, however, that DNA human primase strongly discriminates against polymerizing tC opposite adenines (Urban et al. 2010). In addition to these DNA polymerization investigations, the ribonucleotide form of $\mathrm{tC}$ has been synthesized and tested as a substrate for T7 RNA polymerase. Interestingly, it was also found in this study that T7 RNA polymerase does not misincorporate $\mathrm{tC}$ opposite adenine and it was shown that the ribonucleotide form of $\mathrm{tC}$ could replace normal cytosine in an $\sim 800$ nucleotide $\mathrm{RNA}$, enabling straightforward fluorescent labelling of long RNAs (Stengel et al. 2010). It is also worth mentioning that for future investigations of polymerases using $\mathrm{tC}$, also the dideoxy derivative has been synthesized (Porterfield \& Tahmassebi, 2009). 


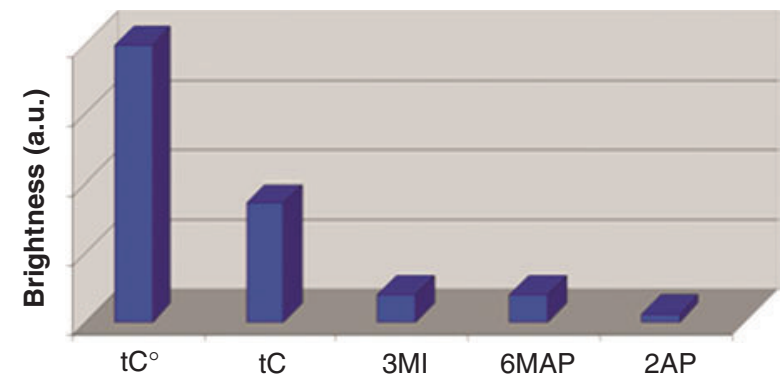

Fig. 13. Average brightness $\left(\propto \varphi_{f} \varepsilon\right)$ of common fluorescent base analogues in dsDNA calculated using values in Sandin et al., Ward et al., Sanabia et al., Driscoll et al., Hawkins et al. and Hawkins (average taken over various surrounding base pairs to the base analogue) (Driscoll et al. 1997; Hawkins, 2001; Hawkins et al. 1995; Sanabia et al. 2004; Sandin et al. 2005, 2008; Ward et al. 1969).

\subsection{3 tC $\mathrm{C}^{\circ}-$ 1,3-diaza-2-oxophenoxazine}

Also the oxo-homologue of $\mathrm{tC}$ called $\mathrm{tC}^{\mathrm{O}}$ (Fig. 11 b), 1,3-diaza-2-oxophenoxazine, was originally developed by Matteucci and co-workers (Lin et al. 1995) and proved to be a good cytosine analogue. Encouraged by the successful development of $\mathrm{tC}$, we started to investigate the spectral properties of $\mathrm{tC}^{\mathrm{O}}$. Like $\mathrm{tC}, \mathrm{tC}^{\mathrm{O}}$ can easily be selectively excited. It has the lowest energy absorption band centred around $365 \mathrm{~nm}$ in duplex DNA as well as in ssDNA (Sandin et al. 2008). This band consists of a single electronic transition polarized $33^{\circ}$ counterclockwise from the long axis of $\mathrm{tC}^{\mathrm{O}}$. Furthermore, the emission maximum of $\mathrm{tC}^{\mathrm{O}}$ is situated at $455 \mathrm{~nm}$; its quantum yield in duplex DNA was found to be high $\left(\varphi_{f}=0.22\right.$ on average $)$ and the decay mono-exponential (Sandin et al. 2008). In combination with a high molar absorptivity $\left(\varepsilon=9000 \mathrm{M}^{-1} \mathrm{~cm}^{-1}\right)$ for a base analogue, this makes $\mathrm{tC}^{\mathrm{O}}$ on average the brightest fluorescent base analogue in duplex context currently available. It is more than two times brighter on average than $\mathrm{tC}$ and up to 10-50 times brighter than fluorescent base analogues like 3-MI, 6-MAP and 2-AP (Fig. 13). It should be pointed out that some of these base analogues even have higher brightness values than $\mathrm{tC}^{\mathrm{O}}$ for certain sequences, but on average they are considerably less bright. In contrast to $\mathrm{tC}$ and to the case for $\mathrm{tC}^{\mathrm{O}}$ in duplex, the quantum yield of $\mathrm{tC}^{\mathrm{O}}$ is sensitive to its surrounding bases in the single-stranded case $\left(\varphi_{f}=0 \cdot 14-0.41\right)$; in addition, the fluorescence decays in general need bi-exponential expressions to be adequately fitted (Sandin et al. 2008). This difference distinguishes the photophysical properties of $\mathrm{tC}^{\mathrm{O}}$ in the single- and double-stranded case and, thus, it is possible to use $\mathrm{tC}^{\mathrm{O}}$ as a probe of nucleic acid secondary (and tertiary) structure (vide infra).

We also found that $\mathrm{tC}^{\mathrm{O}}$, like $\mathrm{tC}$, stabilizes a DNA duplex by approximately $3{ }^{\circ} \mathrm{C}$ (Sandin $e t$ al. 2008). Furthermore, we demonstrated that with an intelligent choice of neighbouring bases (GT, AA and AC) the change in duplex stability can be reduced to zero. Using $C D$, we established that duplexes containing a $\mathrm{tC}^{\mathrm{O}}$ in place of a cytosine still exist in the natural B-form (Sandin et al. 2008). Further evidence of $\mathrm{tC}^{\mathrm{O}}$ being a non-perturbing base analogue that is nicely base paired and firmly stacked in the duplex comes from fluorescence anisotropy measurements. In these experiments, it was shown that the emission of $\mathrm{tC}^{\mathrm{O}}$ reports on the overall mobility of the DNA duplex without any interference from intrinsic mobility of the base analogue itself (Sandin et al. 2008).

Apart from the study mentioned above where $\mathrm{tC}^{\mathrm{O}}$ reports on the mobility of a nucleic acid system, we have recently used it in two studies for monitoring nucleic acid sequence 
and structure. In the first study, we show that $\mathrm{tC}^{\mathrm{O}}$ can be used as an excellent probe for the detection of individual melting processes of complex nucleic acid structures containing a large number of separate secondary structure motifs (Börjesson et al. 2009b). Since conventional UV-melting investigations only monitor the global melting process of the whole nucleic acid structure, e.g. multi-hairpin systems in RNA/DNA, and thus are incapable of estimating individual melting transitions of such systems, $\mathrm{tC}^{\mathrm{O}}$ represents a new method of characterization. Furthermore, we found in that study that $\mathrm{tC}^{\mathrm{O}}$ may be used to detect bulges and loops in nucleic acids as well as to distinguish a matched base pair from several of the mismatched. In the other study, we used the fluorescence properties of $\mathrm{tC}^{\mathrm{O}}$ to successfully probe the individual melting of all six sides in a DNA nanohexagon after repeated failures using commercially available covalently attached FRET probes (Sandin et al. 2009b). The commercial probes proved to disturb the efficiency of cyclization of this DNA nanoconstruct. In addition to these applications, derivatives of $\mathrm{tC}^{\mathrm{O}}$, including the G-clamp (Lin \& Matteucci, 1998; Nakagawa et al. 2007; Ortega et al. 2007; Rajeev et al. 2001) that increases base-pair stability as well as the rigid nitroxid spin label, Ç (Barhate et al. 2007; Cekan \& Sigurdsson, 2008), have also been developed and used. Finally, it should be mentioned again that $\mathrm{tC}^{\mathrm{O}}$ has been used in studies concerning DNA polymerases (vide supra) (Sandin et al. 2009a; Stengel et al. 2009a) as well as for high density labelling of polymerase chain reaction (PCR) products using the Deep Vent DNA polymerase (Stengel et al. 2009b).

\subsubsection{Development of the first base analogue FRET pair}

As discussed above, $\mathrm{tC} / \mathrm{t} \mathrm{C}^{\mathrm{O}}$ have several properties that make them ideally suited as FRET donors in nucleic acid systems: (1) a high and virtually unaffected quantum yield $\left(\varphi_{D}\right),(2)$ a high control of orientation and position within the nucleic acid $\left(\kappa^{2}\right)$, (3) minimal perturbation to the structure of the nucleic acid, and (4) the possibility of having the probe close to the site of examination. The first two properties are important in order to have a high control of the Förster distance $\left(R_{0}\right.$; Eq. 1$)$, which is essential to know in order to be able to determine distances $\left(R_{\mathrm{DA}}\right.$, distance between the donor and acceptor) using FRET efficiency ( $E$; Eq. 2).

$R_{0}=0 \cdot 211\left(J_{\mathrm{DA}} \kappa^{2} n^{-4} \phi_{\mathrm{D}}\right)^{1 / 6}$ in $\AA$,

$E=R_{0}^{6} /\left(R_{0}^{6}+R_{\mathrm{DA}}^{6}\right)$.

The geometric factor $\left(\kappa^{2}\right)$ takes the direction of the donor and acceptor transition dipoles into consideration and is described by Eq. (3):

$\kappa=\boldsymbol{e}_{1} \cdot \boldsymbol{e}_{2}-3\left(\boldsymbol{e}_{1} \cdot \boldsymbol{e}_{12}\right)\left(\boldsymbol{e}_{12} \cdot \boldsymbol{e}_{2}\right)$,

where $\boldsymbol{e}_{1}$ and $\boldsymbol{e}_{2}$ are unit vectors of the donor and acceptor transition dipoles and $\boldsymbol{e}_{12}$ is the unit vector between their centres. The value of $\kappa^{2}$ can range from 0 to 4 . Thus, to be able to extract detailed structural information from the measured FRET efficiency, an accurate estimate of $\kappa^{2}$ is required. The most frequently used (both correctly and incorrectly) $\kappa^{2}$ is $2 / 3$, which corresponds to freely rotating donor and acceptor transition dipoles and is therefore generally used in the case of donors and acceptors that are covalently attached using flexible linkers (e.g. rhodamines, fluoresceins, Cy dyes and Alexa dyes). However, several of these donor/acceptor chromophores interact with the nucleic acid structure (Dolghih et al. 2007; Iqbal et al. 2008b; 


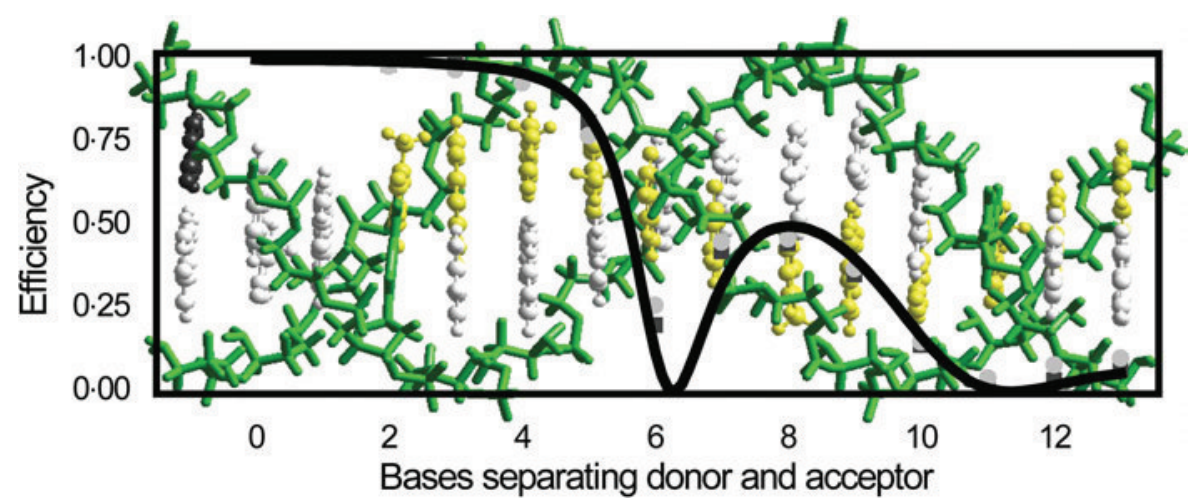

Fig. 14. Efficiency of energy transfer for the base analogue FRET-pair $t \mathrm{C}^{\mathrm{O}}-\mathrm{t} \mathrm{C}_{\text {nitro }}$ estimated using decreases in $\mathrm{tC}^{\mathrm{O}}$ emission (light grey circles) and $\mathrm{tC}^{\mathrm{O}}$ average lifetimes (dark grey squares) as the two analogues are separated by $2-13$ bases in a DNA duplex.

Norman et al. 2000), and thus the use of a $\kappa^{2}$ of $2 / 3$ may be an inaccurate assumption that results in considerable errors in structural interpretations. Various excellent investigations, such as those by Lewis et al., Iqbal et al. and Hurley and Tor have achieved an improved control of the FRET orientation factor in nucleic acid systems (Hurley \& Tor, 2002; Iqbal et al. 2008a; Lewis et al. 2005).

In an attempt to achieve the highest possible control of donor/acceptor orientation in nucleic acid systems, we have therefore developed a novel FRET pair composed of $\mathrm{tC}^{\mathrm{O}}$ as the donor and $\mathrm{tC}_{\text {nitro }}$ (Fig. $11 c$ ) as the acceptor (Börjesson et al. 2009a). As for the other two members of the tricyclic cytosine family, $\mathrm{tC}_{\text {nitro }}$ was shown to give minimal perturbation to both the structure and stability of DNA. The lowest energy absorption of $\mathrm{tC}_{\text {nitro }}$ has a peak at approximately $440 \mathrm{~nm}$, oriented $\sim 27^{\circ}$ clockwise from the molecular long axis towards the nitro group, resulting in a good overlap with the emission of $\mathrm{tC}^{\mathrm{O}}$ (and $\mathrm{tC}$ ) (Preus et al. 2010). In the investigations, we used a set of oligonucleotides that gave us the possibility of monitoring the FRET efficiency between $\mathrm{tC}^{\mathrm{O}}$ and $\mathrm{tC}_{\text {nitro }}$ separated by $2-13$ bases (approx. $10-50 \AA$ ). The results in Fig. 14 show a FRET efficiency that is highly dependent on both distance and orientation (oscillates with $\cos ^{2}$ of the angle between the transition dipole moments of the donor and acceptor), which is expected for two chromophores that are firmly stacked in their positions during the lifetime of donor fluorescence. The data suggest that we have successfully designed an excellent nucleic acid base analogue FRET pair covering up to more than one turn of B-form DNA (Börjesson et al. 2009a).

In conclusion, $\mathrm{tC}^{\mathrm{O}}$ and $\mathrm{tC}_{\text {nitro }}$ constitute the first nucleic acid base analogue FRET pair. As a consequence of the unique property of both the analogues being rigidly located within the base stack and the donor quantum yield being stable, this system enables very high control of the Förster distance. A set of strands containing the FRET pair at strategically chosen positions, that is, where the slopes are steep in Fig. 14, will, hence, make it possible to accurately distinguish distance from orientation changes using FRET. In combination with the favourable base-pairing properties, this will facilitate detailed studies of the inherent dynamics of nucleic acid structures. Moreover, the placement of FRET-pair chromophores inside the base stack will be a great advantage in studies where other (biomacro)molecules interact with the nucleic acid. 


\section{Conclusions}

When selecting the best or at least an appropriate fluorescent probe for the nucleic acidcontaining system under investigation, there are several fluorophores to choose among ranging from large covalently attached external fluorophores like fluoresceins, rhodamines, Cy dyes or Alexa dyes to fluorescent base analogues with normal base-pairing properties. Either external or internal modification could be preferable and, therefore, it is impossible and incorrect to claim that a certain fluorophore or even group of fluorophores is, overall, best suited for fluorescently modifying DNA. Instead one needs to carefully consider each system under examination and try to optimize the choice of fluorescent probe molecule thereafter. However, with the increasing number of promising fluorescent base analogues developed in recent years as well as an enhanced sensitivity of fluorescence equipments, the odds of finding a base analogue that is appropriate for the required investigation has increased dramatically. There is no doubt that several of the current fluorescent base analogues have enabled some previously impossible investigations and in combination with the fact that there is still a large need for novel fluorescent base analogues of all the natural bases with improved as well as different spectral and photophysical properties, the development of this kind of fluorophore will be of great importance for a long time to come.

This review strives to cover the current state of the art in fluorescent nucleic acid base analogues. However, as with any review it is by no means fully comprehensive. To get a more complete picture of the whole literature of this field, readers could also refer to the excellent reviews by Millar, Rist and Marino, Asseline, Wilson and Kool as well as other reviews mentioned above (Asseline, 2006; Millar, 1996; Rist \& Marino, 2002; Wilson \& Kool, 2006).

\section{Acknowledgements}

This work was supported by the Swedish Research Council. I wish to thank all the co-authors of my articles concerning the tricyclic cytosine analogues and special thanks go to Dr Peter Sandin, Karl Börjesson, Dr Gudrun Stengel, Søren Preus as well as Professor Tom Brown and his group at University of Southampton, UK.

\section{References}

Albert, A. \& Taguchi, H. (1973). Ultraviolet spectral correlation between cation of an amino-n-heteroaromatic compound and neutral species of correpsonding oxo-analog. Journal of the Chemical Society, Perkin Transactions 2 8, 1101-1103.

Aldaye, F. A. \& Sleiman, H. F. (2006). Sequential selfassembly of a DNA hexagon as a template for the organization of gold nanoparticles. Angewandte Chemie International Edition 45, 2204-2209.

Allan, B. W. \& Reich, N. O. (1996). Targeted base stacking disruption by the EcoRI DNA methyltransferase. Biochemistry 35, 14757-14762.

Asseline, U. (2006). Development and applications of fluorescent oligonucleotides. Current Organic Chemistry 10, 491-518.
Augustyn, K. E., Wojtuszewski, K., Hawkins, M. E., Knutson, J. R. \& Mukerji, I. (2006). Examination of the premelting transition of DNA A-tracts using a fluorescent adenosine analogue. Biochemistry 45, 5039-5047.

Bag, S. S., Saito, Y., Hanawa, K., Kodate, S., Suzuka, I. \& SAITO, I. (2006). Intelligent fluorescent nucleoside in sensing cytosine base: importance of hydrophobic nature of perylene fluorophore. Bioorganic and Medicinal Chemistry Letters 16, 6338-6341.

Barhate, N., Cekan, P., Massey, A. P. \& Sigurdsson, S. T. (2007). A nucleoside that contains a rigid nitroxide spin label: a fluorophore in disguise. Angewandte Chemie International Edition 46, 2655-2658.

Berger, M., Ogawa, A. K., Mcminn, D. L., Wu, Y. Q., Schultz, P. G. \& Romesberg, F. E. (2000). Stable and selective hybridization of oligonucleotides with 
unnatural hydrophobic bases. Angewandte Chemie International Edition 39, 2940-2942.

Bergstrom, D. E., Inoue, H. \& Reddy, P. A. (1982). Pyrido[2,3-D]pyrimidine nucleosides - synthesis via cyclization of C-5-substituted cytidines. Journal of Organic Chemistry 47, 2174-2178.

Berry, D. A., Jung, K. Y., Wise, D. S., Sercel, A. D., Pearson, W. H., Mackie, H., Randolph, J. B. \& Somers, R. L. (2004). Pyrrolo-dC and pyrrolo-C: fluorescent analogs of cytidine and 2'-deoxycytidine for the study of oligonucleotides. Tetrahedron Letters 45, 24572461.

Bloom, L. B., Оtтo, M. R., Beechem, J. M. \& Goodman, M. F. (1993). Influence of 5 -nearest neighbors on the insertion kinetics of the fluorescent nucleotide analog 2-aminopurine by Klenow fragment. Biochemistry 32, 11247-11258.

Börjesson, K., Preus, S., El-Sagheer, A. H., Brown, T., Albinsson, B. \& Wilhelmsson, L. M. (2009a). Nucleic acid base analog FRET-pair facilitating detailed structural measurements in nucleic acid containing systems. Journal of the American Chemical Society 131, 4288-4293.

Börjesson, K., Sandin, P. \& Wilhelmsson, L. M. (2009b). Nucleic acid structure and sequence probing using fluorescent base analogue $\mathrm{tC}^{\mathrm{O}}$. Biophysical Chemistry 139, $24-28$.

Cekan, P. \& Sigurdsson, S. T. (2008). Single base interrogation by a fluorescent nucleotide: each of the four DNA bases identified by fluorescence spectroscopy. Chemical Communications 29, 3393-3395.

Dash, C., Rausch, J. W. \& Le Grice, S. F. J. (2004). Using pyrrolo-deoxycytosine to probe RNA/DNA hybrids containing the human immunodeficiency virus type-1 3' polypurine tract. Nucleic Acids Research 32, 1539-1547.

Dolghin, E., Roitberg, A. E. \& Krause, J. L. (2007). Fluorescence resonance energy transfer in dye-labeled DNA. Journal of Photochemistry and Photobiology A: Chemistry 190, 321-327.

Driscoll, S. L., Hawkins, M. E., Balis, F. M., Pfleiderer, W. \& Laws, W. R. (1997). Fluorescence properties of a new guanosine analog incorporated into small oligonucleotides. Biophysical Journal 73, 3277-3286.

Dyrager, C., Börjesson, K., Diner, P., Elf, A., Albinsson, B., Wilhelmsson, L. M. \& Grøtli, M. (2009). Synthesis and photophysical characterisation of fluorescent 8-(1H-1,2,3-Triazol-4-yl)adenosine derivatives. European Journal of Organic Chemistry 10, 15151521.

Eldrup, A. B., Nielsen, B. B., Haaima, G., Rasmussen, H., Kastrup, J. S., Christensen, C. \& Nielsen, P. E. (2001). 1,8-Naphthyridin-2(1H)-ones - novel bicyclic and tricyclic analogues of thymine in peptide nucleic acids (PNAs). European Journal of Organic Chemistry 9, 17811790.

Engman, K. C., Sandin, P., Osborne, S., Brown, T., Billeter, M., Lincoln, P., Nordén, B., Albinsson, B.
\& Wilhelmsson, L. M. (2004). DNA adopts normal B-form upon incorporation of highly fluorescent DNA base analogue tC: NMR structure and UV-Vis spectroscopy characterization. Nucleic Acids Research 32, 5087-5095.

Freese, E. (1959). Specific mutagenic effect of base analogues on phage-T4. Journal of Molecular Biology 1, 87-105.

Gao, J. M., Strassler, C., Tahmassebi, D. \& Kool, E. T. (2002). Libraries of composite polyfluors built from fluorescent deoxyribosides. Journal of the American Chemical Society 124, 11590-11591.

Gilbert, S. D., Stoddard, C. D., Wise, S. J. \& Batey, R. T. (2006). Thermodynamic and kinetic characterization of ligand binding to the purine riboswitch aptamer domain. Journal of Molecular Biology 359, 754-768.

Godde, F., Toulme, J. J. \& Moreau, S. (1998). Benzoquinazoline derivatives as substitutes for thymine in nucleic acid complexes. Use of fluorescence emission of benzo[g]quinazoline-2,4-(1H,3H)-dione in probing duplex and triplex formation. Biochemistry 37, 1376513775.

Godde, F., Toulme, J. J. \& Moreau, S. (2000). 4-amino1H-benzo[g]quinazoline-2-one: a fluorescent analog of cytosine to probe protonation sites in triplex forming oligonucleotides. Nucleic Acids Research 28, 2977-2985.

Greco, N. J., Sinkeldam, R. W. \& Tor, Y. (2009). An emissive $C$ analog distinguishes between $G$, 8-oxoG, and T. Organic Letters 11, 1115-1118.

Greco, N. J. \& Tor, Y. (2005). Simple fluorescent pyrimidine analogues detect the presence of DNA abasic sites. Journal of the American Chemical Society 127, 10784-10785.

Greco, N. J. \& Tor, Y. (2007). Furan decorated nucleoside analogues as fluorescent probes: synthesis, photophysical evaluation, and site-specific incorporation. Tetrahedron 63, 3515-3527.

Guest， C. R., Hochstrasser, R. A., Sowers, L. C. \& Millar, D. P. (1991). Dynamics of mismatched basepairs in DNA. Biochemistry 30, 3271-3279.

Hardman, S. J. O. \& Thompson, K. C. (2006). Influence of base stacking and hydrogen bonding on the fluorescence of 2-aminopurine and pyrrolocytosine in nucleic acids. Biochemistry 45, 9145-9155.

Hawkins, M. E. (2001). Fluorescent pteridine nucleoside analogs - a window on DNA interactions. Cell Biochemistry and Biophysics 34, 257-281.

Hawkins, M. E. \& Balis, F. M. (2004). Use of pteridine nucleoside analogs as hybridization probes. Nucleic Acids Research 32, e62, doi:10.1093/nar/gnh060.

Hawkins, M. E., Pfleiderer, W., Balis, F. M., Porter, D. \& Knutson, J. R. (1997). Fluorescence properties of pteridine nucleoside analogs as monomers and incorporated into oligonucleotides. Analytical Biochemistry 244, 86-95.

Hawkins, M. E., Pfleiderer, W., Jungmann, O. \& Balis, F. M. (2001). Synthesis and fluorescence 
characterization of pteridine adenosine nucleoside analogs for DNA incorporation. Analytical Biochemistry 298, 231-240.

Hawkins, M. E., Pfleiderer, W., Mazumder, A., Pommier, Y. G. \& FALls, F. M. (1995). Incorporation of a fluorescent guanosine analog into oligonucleotides and its application to a real-time assay for the Hiv-1 integrase 3'-processing reaction. Nucleic Acids Research 23, 2872-2880.

Hochstrasser, R. A., Carver, T. E., Sowers, L. C. \& Millar, D. P. (1994). Melting of a DNA helix terminus within the active-site of a DNA-polymerase. Biochemistry 33, 11971-11979.

Holmén, A., Nordén, B. \& Albinsson, B. (1997). Electronic transition moments of 2-aminopurine. Journal of the American Chemical Society 119, 3114-3121.

Hu, J., Dodd, D. W., Hudson, R. H. E. \& Corey, D. R. (2009). Cellular localization and allele-selective inhibition of mutant huntingtin protein by peptide nucleic acid oligomers containing the fluorescent nucleobase [bis-o-(aminoethoxy)phenyl]pyrrolocytosine. Bioorganic and Medicinal Chemistry Letters 19, 6181-6184.

Hudson, R. H. E. \& Ghorbani-Choghamarani, A. (2007). Oligodeoxynucleotides incorporating structurally simple 5-alkynyl-2'-deoxyuridines fluorometrically respond to hybridization. Organic and Biomolecular Chemistry 5, 1845 1848.

Hudson, R. H. E., Vilrre, R. D., Liu, Y. H., Wojciechowski, F. \& Dambenieks, A. K. (2003). Chemistry for the synthesis of nucleobase-modified peptide nucleic acid. In 39th IUPAC Congress/86th Conference of the Canadian Society for Chemistry, Ottawa, Canada, p. 1591-1598.

Hurley, D. J. \& Tor, Y. (2002). Donor/acceptor interactions in systematically modified Ru-II-Os-II oligonucleotides. Journal of the American Chemical Society 124, 13231-13241.

Inoue, H., Imura, A. \& Ohtsuka, E. (1987). Synthesis of dodecadeoxyribonucleotides containing pyrrolo[2,3d]pyrimidine nucleoside and their base-pairing ability. Nippon Kagaku Kaishi 7, 1214-1220.

Iqbal, A., Arslan, S., Okumus, B., Wilson, T. J., Giraud, G., Norman, D. G., Ha, T. \& Lilley, D. M. J. (2008a). Orientation dependence in fluorescent energy transfer between Cy3 and Cy5 terminally attached to doublestranded nucleic acids. Proceedings of the National Academy of Sciences of the United States of America 105, 11176-11181.

Iqbal, A., Wang, L., Thompson, K. C., Lilley, D. M. J. \& Norman, D. G. (2008b). The structure of cyanine 5 terminally attached to double-stranded DNA: implications for FRET studies. Biochemistry 47, 7857-7862.

Joyce, C. M., Potapova, O., Delucia, A. M., Huang, X. W., Basu, V.P. \& Grindley, N. D. F. (2008). Fingers-closing and other rapid conformational changes in DNA polymerase I (Klenow fragment) and their role in nucleotide selectivity. Biochemistry 47, 6103-6116.
Kelley, S. O. \& Barton, J. K. (1999). Electron transfer between bases in double helical DNA. Science 283, 375-381.

Laland, S. G. \& Serckhanssen, G. (1964). Synthesis of pyrimidin-2-1 deoxyribosides and their ability to support growth of deoxyriboside-requiring organism lactobacillus acidophilus R26. Biochemical Journal 90, 76-81.

Lemay, J. F., Penedo, J. C., Tremblay, R., Lilley, D. M. J. \& Lafontaine, D. A. (2006). Folding of the adenine riboswitch. Chemistry \& Biology 13, 857-868.

Lewis, F. D., Zhang, L. G. \& Zuo, X. B. (2005). Orientation control of fluorescence resonance energy transfer using DNA as a helical scaffold. Journal of the American Chemical Society 127, 10002-10003.

Lin, K., Jones, R. J. \& Matteucci, M. D. (1995). Tricyclic 2 -deoxycytidine analogs - syntheses and incorporation into oligodeoxynucleotides which have enhanced binding to complementary RNA. Journal of the American Chemical Society 117, 3873-3874.

Lin, K. Y. \& Matteucci, M. D. (1998). A cytosine analogue capable of clamp-like binding to a guanine in helical nucleic acids. Journal of the American Chemical Society 120, 8531-8532.

Liu, C. H. \& Martin, C. T. (2001). Fluorescence characterization of the transcription bubble in elongation complexes of T7 RNA polymerase. Journal of Molecular Biology 308, 465-475.

Lycksell, P. O., Gräslund, A., Claesens, F., Mclaughlin, L. W., Larsson, U. \& Rigler, R. (1987). Base pair opening dynamics of a 2-aminopurine substituted EcoRI restriction sequence and its unsubstituted counterpart in oligonucleotides. Nucleic Acids Research 15, 9011-9025.

Marti, A. A., Jockusch, S., Li, Z. M., Ju, J. Y. \& Turro, N. J. (2006). Molecular beacons with intrinsically fluorescent nucleotides. Nucleic Acids Research 34, e50.

Matray, T. J. \& Kool, E. T. (1999). A specific partner for abasic damage in DNA. Nature 399, 704-708.

Matsuda, S. \& Romesberg, F. E. (2004). Optimization of interstrand hydrophobic packing interactions within unnatural DNA base pairs. Journal of the American Chemical Society 126 14419-14427.

Mayer, E., Valis, L., Wagner, C., Rist, M., Amann, N. \& WAGENKNECHT, H. A. (2004). 1-ethynylpyrene as a tunable and versatile molecular beacon for DNA. ChemBioChem 5, 865-868.

Millar, D. P. (1996). Fluorescence studies of DNA and RNA structure and dynamics. Current Opinion in Structural Biology 6, 322-326.

Miyata, K., Mineo, R., Tamamushi, R., Mizuta, M., Ohkubo, A., Taguchi, H., Seio, K., Santa, T. \& SEKINE, M. (2007). Synthesis and fluorescent properties of bi- and tricyclic 4- $N$-carbamoyldeoxycytidine derivatives. Journal of Organic Chemistry 72, 102-108.

Miyata, K., Tamamushi, R., Ohkubo, A., Taguchi, H., Seio, K., Santa, T. \& Sekine, M. (2006). Synthesis and 
properties of a new fluorescent bicyclic 4- $N$-carbamoyldeoxycytidine derivative. Organic Letters 8, 15451548.

Mizuta, M., Banba, J. I., Kanamori, T., Tawarada, R., Ohkubo, A., Sekine, M. \& Seio, K. (2008). New nucleotide pairs for stable DNA triplexes stabilized by stacking interaction. Journal of the American Chemical Society 130, 9622-9623.

Mizuta, M., Seio, K., Miyata, K. \& Sekine, M. (2007). Fluorescent pyrimidopyrimidoindole nucleosides: Control of photophysical characterizations by substituent effects. Journal of Organic Chemistry 72, 5046-5055.

Mizuta, M., Seio, K., Ohkubo, A. \& Sekine, M. (2009). Fluorescence properties of pyrimidopyrimidoindole nucleoside $\mathrm{dC}(\mathrm{PPI})$ incorporated into oligodeoxynucleotides. Journal of Physical Chemistry B 113, 95629569.

Moser, A. M., Patel, M., Yoo, H., Balis, F. M. \& Hawkins, M. E. (2000). Real-time fluorescence assay for O-6-alkylguanine-DNA alkyltransferase. Analytical Biochemistry 281, 216-222.

Nakagawa, O., Ono, S., Li, Z., Tsujimoto, A. \& Sasaki, S. (2007). Specific fluorescent probe for 8-oxoguanosine. Angewandte Chemie International Edition 46, 4500-4503.

Nordlund, T. M., Andersson, S., Nilsson, L., Rigler, R., Gräslund, A. \& Mclaughlin, L. W. (1989). Structure and dynamics of a fluorescent DNA oligomer containing the EcoRI recognition sequence: fluorescence, molecular dynamics, and NMR studies. Biochemistry 28, 9095-9103.

Norman, D. G., Grainger, R. J., Uhrin, D. \& Lilley, D. M. J. (2000). Location of cyanine-3 on doublestranded DNA: importance for fluorescence resonance energy transfer studies. Biochemistry 39, 6317-6324.

Ogawa, A. K., Wu, Y. Q., Berger, M., Schultz, P. G. \& Romesberg, F. E. (2000a). Rational design of an unnatural base pair with increased kinetic selectivity. Journal of the American Chemical Society 122, 8803-8804.

Ogawa, A. K., Wu, Y. Q., Mcminn, D. L., Liu, J. Q., Schultz, P. G. \& Romesberg, F. E. (2000b). Efforts toward the expansion of the genetic alphabet: Information storage and replication with unnatural hydrophobic base pairs. Journal of the American Chemical Society 122, 3274-3287.

Okamoto, A., Saito, Y. \& Saito, I. (2005). Design of base-discriminating fluorescent nucleosides. Journal of Photochemistry and Photobiology C: Photochemistry Reviews 6, 108-122.

Okamoto, A., Tainaka, K. \& Saito, I. (2003a). Clear distinction of purine bases on the complementary strand by a fluorescence change of a novel fluorescent nucleoside. Journal of the American Chemical Society 125, 4972-4973.

Okamoto, A., Tainaka, K. \& Saito, I. (2003b). Synthesis and properties of a novel fluorescent nucleobase, naphthopyridopyrimidine. Tetrahedron Letters 44, 68716874.

Okamoto, A., Tanaka, K., Fukuta, T. \& Saito, I. (2003c). Design of base-discriminating fluorescent nucleoside and its application to T/C SNP typing. Journal of the American Chemical Society 125, 9296-9297.

Okamoto, A., Tanaka, K., Fukuta, T. \& Saito, I. (2004). Cytosine detection by a fluorescein-labeled probe containing base-discriminating fluorescent nucleobase. ChemBioChem 5, 958-963.

Ortega, J. A., Blas, J. R., Orozco, M., Grandas, A., Pedroso, E. \& Robles, J. (2007). Binding affinities of oligonucleotides and PNAs containing phenoxazine and g-clamp cytosine analogues are unusually sequencedependent. Organic Letters 9, 4503-4506.

Piccirilli, J. A., Krauch, T., Moroney, S. E. \& Benner, S. A. (1990). Enzymatic incorporation of a new base pair into DNA and RNA extends the genetic alphabet. Nature 343, 33-37.

Porterfield, W. \& Tahmassebi, D. C. (2009). Synthesis of a fluorescent 2(3'-dideoxycytosine analog, tCdd. Bioorganic and Medicinal Chemistry Letters 19, 111-113.

Preus, S., Börjesson, K., Kilsi̊, K., Albinsson, B. \& Wilhelmsson, L. M. (2010). Characterization of nucleobase analogue FRET acceptor $\mathrm{tC}_{\text {nitro }}$. Journal of Physical Chemistry B 114, 1050-1056.

Rachofsky, E. L., Osman, R. \& Ross, J. B. A. (2001). Probing structure and dynamics of DNA with 2aminopurine: effects of local environment on fluorescence. Biochemistry 40, 946-956.

Rajeev, K. G., Maier, M. A., Lesnik, E. A. \& Manoharan, M. (2001). High-affinity peptide nucleic acid oligomers containing tricyclic cytosine analogues. In 222nd National Meeting of the American Chemical Society, Chicago, Illinois, p. 4395-4398.

Ranasinghe, R. T., Rusling, D. A., Powers, V. E. C., Fox, K. R. \& Brown, T. (2005). Recognition of CG inversions in DNA triple helices by methylated 3H-pyrrolo[2,3-d] pyrimidin-2(7H)-one nucleoside analogues. Chemical Communications 20, 2555-2557.

Ren, R. X. F., Chaudhuri, N. C., Paris, P. L., Rumney, S. \& Kool, E. T. (1996). Naphthalene, phenanthrene, and pyrene as DNA base analogues: Synthesis, structure, and fluorescence in DNA. Journal of the American Chemical Society 118, 7671-7678.

Rist, M. J. \& Marino, J. P. (2002). Fluorescent nucleotide base analogs as probes of nucleic acid structure, dynamics and interactions. Current Organic Chemistry 6, 775-793.

Roca, A. I. \& Singleton, S. F. (2003). Direct evaluation of a mechanism for activation of the RecA nucleoprotein filament. Journal of the American Chemical Society 125, 15366-15375.

Saito, Y., Bag, S.S., Kusakabe, Y., Nagai, C., Matsumoto, K., Mizuno, E., Kodate, S., Suzuka, I. \& SAito, I. (2007). Dual-labeled oligonucleotide probe 
for sensing adenosine via FRET: A novel alternative to SNPs genotyping. Chemical Communications 21, 2133 2135.

Saito, Y., Hanawa, K., Kawasaki, N., Bag, S. S. \& Saito, I. (2006). Acridone-labeled base-discriminating fluorescence (BDF) nucleoside: Synthesis and their photophysical properties. Chemistry Letters 35, 1182-1183.

Saito, Y., Hanawa, K., Motegi, K., Омотo, K., Окамото, A. \& Saito, I. (2005). Synthesis and properties of purine-type base-discriminating fluorescent (BDF) nucleosides: distinction of thymine by fluorescence-labeled deoxyadenosine derivatives. Tetrabedron Letters 46, 7605-7608.

Saito, Y., Motegi, K., Bag, S. S. \& Saito, I. (2008). Anthracene based base-discriminating fluorescent oligonucleotide probes for SNPs typing: Synthesis and photophysical properties. Bioorganic and Medicinal Chemistry 16, 107-113.

Sanabia, J. E., Goldner, L. S., Lacaze, P. A. \& Hawkins, M. E. (2004). On the feasibility of single-molecule detection of the guanosine-analogue 3-MI. Journal of Physical Chemistry B 108, 15293-15300.

Sandin, P., Börjesson, K., Li, H., MÅrtensson, J., Brown, T., Wilhelmsson, L. M. \& Albinsson, B. (2008). Characterization and use of an unprecedentedly bright and structurally non-perturbing fluorescent DNA base analogue. Nucleic Acids Research 36, 157-167.

Sandin, P., Lincoln, P., Brown, T. \& Wilhelmsson, L. M. (2007). Synthesis and oligonucleotide incorporation of fluorescent cytosine analogue $\mathrm{tC}$ : a promising nucleic acid probe. Nature Protocols 2, 615-623.

Sandin, P., Stengel, G., Ljungdahl, T., Börjesson, K., Macao, B. \& Wilhelmsson, L. M. (2009a). Highly efficient incorporation of the fluorescent nucleotide analogs $\mathrm{tC}$ and $\mathrm{tC}^{\mathrm{O}}$ by Klenow fragment. Nucleic Acids Research 37, 3924-3933.

Sandin, P., Tumpane, J., Börjesson, K., Wilhelmsson, L. M., Brown, T., Nordén, B., Albinsson, B. \& Lincoln, P. (2009b). Thermodynamic aspects of DNA nanoconstruct stability and design. Journal of Physical Chemistry C 113, 5941-5946.

Sandin, P., Wilhelmsson, L. M., Lincoln, P., Powers, V. E. C., Brown, T. \& Albinsson, B. (2005). Fluorescent properties of DNA base analogue tC upon incorporation into DNA - negligible influence of neighbouring bases on fluorescence quantum yield. Nucleic Acids Research 33, 5019-5025.

Schneider, K. C. \& Benner, S. A. (1990). Oligonucleotides containing flexible nucleoside analogs. Journal of the American Chemical Society 112, 453-455.

Secrist, J. A., Barrio, J. R. \& Leonard, N. J. (1972). Fluorescent modification of adenosine triphosphate with activity in enzyme systems: $1, N^{6}$-ethenoadenosine triphosphate. Science 175, 646-647.

Seela, F. \& Sirivolu, V. R. (2008). Pyrrolo-dC oligonucleotides bearing alkynyl side chains with terminal triple bonds: synthesis, base pairing and fluorescent dye conjugates prepared by the azide-alkyne "click" reaction. Organic and Biomolecular Chemistry 6, 1674-1687.

SeEla, F. \& Zulauf, M. (1998). 7-deazaadenine-DNA: Bulky 7-iodo substituents or hydrophobic 7-hexynyl chains are well accommodated in the major groove of oligonucleotide duplexes. Chemistry $-A$ European Journal 4, 1781-1790.

Seela, F., Zulauf, M., Sauer, M. \& Deimel, M. (2000). 7-substituted 7-deaza-2'-deoxyadenosines and 8-aza-7deaza-2'-deoxyadenosines: fluorescence of DNA-base analogues induced by the 7 -alkynyl side chain. Helvetica Chimica Acta 83, 910-927.

SeEman, N. C. (2003). DNA in a material world. Nature 421(6921), 427-431.

Singleton, S. F., Roca, A. I., Lee, A. M. \& Xiao, J. (2007). Probing the structure of RecA-DNA filaments. Advantages of a fluorescent guanine analog. Tetrahedron 63, 3553-3566

Singleton, S. F., Shan, F., Kanan, M. W., Mcintosh, C. M., Stearman, C. J., Helm, J. S. \& Webb, K. J. (2001). Facile synthesis of a fluorescent deoxycytidine analogue suitable for probing the RecA nucleoprotein filament. Organic Letters 3, 3919-3922.

Sinkeldam, R. W., Greco, N. J. \& Tor, Y. (2008). Polarity of major grooves explored by using an isosteric emissive nucleoside. ChemBioChem 9, 706-709.

Sowers, L. C., Boulard, Y. \& Fazakerley, G. V. (2000). Multiple structures for the 2-aminopurine-cytosine mispair. Biochemistry 39, 7613-7620.

Sowers, L. C., Fazakerley, G. V., Eritja, R., Kaplan, B. E. \& Goodman, M. F. (1986). Base pairing and mutagenesis: observation of a protonated base pair between 2-aminopurine and cytosine in an oligonucleotide by proton NMR. Proceedings of the National Academy of Sciences of the United States of America 83, 5434-5438.

Srivatsan, S. G., Greco, N. J. \& Tor, Y. (2008a). A highly emissive fluorescent nucleoside that signals the activity of toxic ribosome-inactivating proteins. Angewandte Chemie International Edition 47, 6661-6665.

Srivatsan, S. G. \& Tor, Y. (2007a). Fluorescent pyrimidine ribonucleotide: Synthesis, enzymatic incorporation, and utilization. Journal of the American Chemical Society 129, 2044-2053.

Srivatsan, S. G. \& Tor, Y. (2007b). Using an emissive uridine analogue for assembling fluorescent HIV-1 TAR constructs. Tetrahedron 63, 3601-3607.

Srivatsan, S. G. \& Tor, Y. (2009). Enzymatic incorporation of emissive pyrimidine ribonucleotides. Chemistry - An Asian Journal 4, 419-427.

Srivatsan, S. G., Weizman, H. \& Tor, Y. (2008b). A highly fluorescent nucleoside analog based on thieno[3,4-d] pyrimidine senses mismatched pairing. Organic and Biomolecular Chemistry 6, 1334-1338. 
Stanley, R. J., Hou, Z. J., Yang, A. P. \& Hawkins, M. E. (2005). The two-photon excitation cross section of 6MAP, a fluorescent adenine analogue. Journal of Physical Chemistry B 109, 3690-3695.

Stengel, G., Gill, J. P., Sandin, P., Wilhelmsson, L. M., Albinsson, B., Nordén, B. \& Millar, D. P. (2007). Conformational dynamics of DNA polymerase probed with a novel fluorescent DNA base analog. Biochemistry 46, 12289-12297.

Stengel, G., Purse, B. W., Wilhelmsson, L. M., Urban, M. \& KuchtA, R. D. (2009a). Ambivalent incorporation of the fluorescent cytosine analogues $\mathrm{tC}$ and tCo by human DNA polymerase alpha and Klenow fragment. Biochemistry 48, 7547-7555.

Stengel, G., Urban, M., Purse, B. W. \& Kuchta, R. D (2009b). High density labeling of polymerase chain reaction products with the fluorescent base analogue tCo. Analytical Chemistry 81, 9079-9085.

Stengel, G., Urban, M., Purse, B. W. \& Kuchta, R. D. (2010). Incorporation of the fluorescent ribonucleotide analogue tCTP by T7 RNA polymerase. Analytical Chemistry 82, 1082-1089.

Stivers, J. T. (1998). 2-aminopurine fluorescence studies of base stacking interactions at abasic sites in DNA: metal-ion and base sequence effects. Nucleic Acids Research 26, 3837-3844.

Stivers, J. T., Pankiewicz, K. W. \& Watanabe, K. A. (1999). Kinetic mechanism of damage site recognition and uracil flipping by Escherichia coli uracil DNA glycosylase. Biochemistry 38, 952-963.

Strässler, C., Davis, N. E. \& Kool, E. T. (1999). Novel nucleoside analogues with fluorophores replacing the DNA base. Helvetica Chimica Acta 82, 2160-2171.

Svanvik, N., Westman, G., Wang, D. Y. \& Kubista, M. (2000). Light-up probes: Thiazole orange-conjugated peptide nucleic acid for detection of target nucleic acid in homogeneous solution. Analytical Biochemistry 281, 26-35.

Switzer, C., Moroney, S. E. \& Benner, S. A. (1989). Enzymatic incorporation of a new base pair into DNA and RNA. Journal of the American Chemical Society 111, 8322-8323.

Switzer, C. Y., Moroney, S. E. \& Benner, S. A. (1993). Enzymatic recognition of the base-pair between isocytidine and isoguanine. Biochemistry 32, 10489-10496.

Tainaka, K., Tanaka, K., Ikeda, S., Nishiza, K., Unzai, T., Fujwara, Y., Saito, I. \& Okamoto, A. (2007). PRODAN-conjugated DNA: synthesis and photochemical properties. Journal of the American Chemical Society 129, 4776-4784.

Tinsley, R. A. \& Walter, N. G. (2006). Pyrrolo-C as a fluorescent probe for monitoring RNA secondary structure formation. $R N A-A$ Publication of the $R N A$ Society 12, 522-529.

Tor, Y., Del Valle, S., Jaramillo, D., Srivatsan, S. G., Rios, A. \& Weizman, H. (2007). Designing new iso- morphic fluorescent nucleobase analogues: the thieno [3,2-d]pyrimidine core. Tetrabedron 63, 3608-3614.

Tumpane, J., Kumar, R., Lundberg, E. P., Sandin, P., Gale, N., Nandhakumar, I. S., Albinsson, B., Lincoln, P., Wilhelmsson, L. M., Brown, T. \& Nordén, B. (2007). Triplex addressability as a basis for functional DNA nanostructures. Nano Letters 7, 3832-3839.

Varghese, R. \& Wagenknecht, H. A. (2009). White-lightemitting DNA (WED). Chemistry - A European Journal 15, 9307-9310.

Urban, M., Joubert, N., Purse, B. W., Hocek, M. \& KuchtA, R. D. (2010). Mechanisms by which human DNA primase chooses to polymerize a nucleoside triphosphate. Biochemistry 49, 727-735.

Ward, D. C., Reich, E. \& Stryer, L. (1969). Fluorescence studies of nucleotides and polynucleotides I. Formycin 2-aminopurine riboside 2,6-diaminopurine riboside and their derivatives. Journal of Biological Chemistry 244, 1228-1237.

Wilhelmsson, L. M., Holmén, A., Lincoln, P., Nielsen, P. E. \& NordéN, B. (2001). A highly fluorescent DNA base analogue that forms Watson-Crick base pairs with guanine. Journal of the American Chemical Society 123, 2434-2435.

Wilhelmsson, L. M., Sandin, P., Holmén, A., Albinsson, B., Lincoln, P. \& Nordén, B. (2003). Photophysical characterization of fluorescent DNA base analogue, $\mathrm{tC}$. Journal of Physical Chemistry B 107, 9094-9101.

Wilson, J. N. \& Kool, E. T. (2006). Fluorescent DNA base replacements: reporters and sensors for biological systems. Organic and Biomolecular Chemistry 4, 4265-4274.

Wojciechowski, F. \& Hudson, R. H. E. (2008). Fluorescence and hybridization properties of peptide nucleic acid containing a substituted phenylpyrrolocytosine designed to engage guanine with an additional H-bond. Journal of the American Chemical Society 130, 12574-12575.

Wojciechowski, F. \& Hudson, R. H. E. (2009). Peptide nucleic acid containing a meta-substituted phenylpyrrolocytosine exhibits a fluorescence response and increased binding affinity toward RNA. Organic Letters 11, 4878-4881.

Wojtuszewski, K., Hawkins, M. E., Cole, J. L. \& Mukerji, I. (2001). HU binding to DNA: Evidence for multiple complex formation and DNA bending. Biochemistry 40, 2588-2598.

Woo, J. S., Meyer, R. B. \& Gamper, H. B. (1996). G/Cmodified oligodeoxynucleotides with selective complementarity: synthesis and hybridization properties. Nucleic Acids Research 24, 2470-2475.

Wu, P. G., Nordlund, T. M., Gildea, B. \& Mclaughlin, L. W. (1990). Base stacking and unstacking as determined from a DNA decamer containing a fluorescent base. Biochemistry 29, 6508-6514.

Xiao, J., Lee, A. M. \& Singleton, S. F. (2006). Construction and evaluation of a kinetic scheme for 
RecA-mediated DNA strand exchange. Biopolymers $\mathbf{8 1}$, 473-496.

XIE, Y., Dix, A. V. \& Tor, Y. (2009). FRET enabled real time detection of RNA-small molecule binding. Journal of the American Chemical Society 131, 17605-17614.

YANG, K. S., MatSiKa, S. \& STANLEY, R. J. (2007). 6MAP, a fluorescent adenine analogue, is a probe of base flipping by DNA photolyase. Journal of Physical Chemistry B 111, 10615-10625.

Yang, K. S. \& Stanley, R. J. (2008). The extent of DNA deformation in DNA photolyase-substrate complexes:
A solution state fluorescence study. Photochemistry and Photobiology 84, 741-749.

Zang, Z., Fang, Q. M., PeggG, A. E. \& Guengerich, F. P. (2005). Kinetic analysis of steps in the repair of damaged DNA by human O-6-alkylguanine-DNA alkyltransferase. Journal of Biological Chemistry 28030873 30881.

ZHANG, X. \& WADKINS, R. M. (2009). DNA hairpins containing the cytidine analog pyrrolo- $\mathrm{dC}$ : structural, thermodynamic, and spectroscopic studies. Biophysical Journal 96, 1884-1891. 